\title{
Glomerulonephritis with coexistent immune deposits and antibasement membrane activity
}

\author{
SRINIVASAN RAJARAMAN, ${ }^{*}$ JOSE A PINTO, $†$ TITO CAVALLO* \\ From the *Renal Immunopathology Division, University of Texas Medical Branch at Galveston, Galveston, \\ Texas, USA, and †Instituto Anatomopatologico Universidad Central, Caracas, Venezuela
}

SUMMARY Six patients with coexistent antiglomerular basement membrane disease and granular immunoreactants in the glomerular basement membrane and mesangium are discussed. These six patients represent $35 \%$ of all patients with antiglomerular basement membrane nephritis examined over 10 years. All patients presented with acute, oliguric renal failure, and rapid deterioration in renal function. In all patients the pathogenetic role of the antiglomerular basement membrane antibody was confirmed by the demonstration of linear deposits of IgG along the glomerular basement membrane and antiglomerular basement membrane antibody activity in the serum or renal eluates, or both. Evidence for the existence of concurrent immune aggregates was obtained by immunofluorescence studies and electron microscopy. Radioimmunoassays, which were performed in two patients to detect circulating immune complexes, however, yielded negative results. The possible mechanisms concerned in the evolution of this condition and their potential implications are reviewed.

Two major nephritogenic immune mechanisms have been implicated in the causation of human glomerulonephritis: the specific interaction of antibodies with antigens that are intrinsic to the glomerular basement membrane (GBM) and the lodging of circulating, nonglomerular, antigenantibody complexes in the glomerulus. Traditionally, glomerulonephritis has been thought to result from either one of these mechanisms, but not both. Anti-GBM nephritis comprises about $2-5 \%$, and immune complex nephritis about $70-80 \%$ of all immunologically mediated glomerulonephritis. ${ }^{12}$ Although much information has been gathered about the pathogenesis of anti-GBM disease, little information is available on the factors that are responsible for the induction of anti-GBM antibody. The inducing factors are probably heterogeneous and may include injury to the capillary wall, as in some cases of idiopathic membranous glomerulonephritis ${ }^{34}$; penicillamine treatment ${ }^{5}$; viral influenza ${ }^{6}$; other associated GBM disease (for example Nail-Patella syndrome) ${ }^{7}$; volatile hydrocarbon exposure ${ }^{8}$; traumatic renal cortical necrosis';

Accepted for publication 17 October 1983 and Hodgkin's and non-Hodgkin's lymphomata. ${ }^{10}$

Recently, a few patients with features of both immune complex nephritis and anti-GBM antibody mediated nephritis have been described, ${ }^{11-17}$ raising the possibility of yet another range of clinicopathological entities. This report describes the immunopathological features of six patients who had both anti-GBM disease and granular immunoreactants in glomeruli.

\section{Material and methods}

A total of 1956 consecutive renal biopsy specimens were examined over 10 years from 1972 to 1982 . Seventeen specimens $(0.9 \%)$ fulfilled the clinical, morphological, and immunopathological criteria for anti-GBM disease. ${ }^{14} \mathrm{Six}$ of these $17(35 \%)$ also showed evidence of deposition of immunoreactants in the kidneys. These six cases are discussed in this report. Whole kidneys were also available for study in four of these patients.

The procedures for processing tissue for light, immunofluorescence, and electron microscopy; the controls for ascertaining the specificity of the reagents used; and the instruments for assessing tissue changes were similar to those described in an earlier 
report. ${ }^{18}$ An average of 47 glomeruli (range eight to 100) were studied by light and immunofluorescence microscopy. For immunofluorescence studies the sections were stained with antisera to human IgG, IgM, IgA, C1q, C3, C4, fibrin-related-antigens, albumin, and alpha-2-macroglobulin. An arbitrary scale of $0-3+$ was used to indicate the intensity of fluorescent deposits. ${ }^{19}$ One to three glomeruli from each biopsy were studied ultrastructurally.

Anti-GBM activity in the sera and renal eluates was assessed by an indirect immunofluorescence assay. ${ }^{19}$ Renal eluates were obtained by extraction in citrate buffer ( $\mathrm{pH} 3 \cdot 2$ ). ${ }^{19}$ Radioimmunoassays to detect anti-GBM antibody in the sera and renal eluates from four patients, and radioimmunoassays (C1q binding assay and Raji cell assays) to detect circulating immune complexes in the sera of two patients, were performed by Dr Curtis Wilson.

Some observations on three of our patients (cases 1,2 , and 3) have already been published. ${ }^{19}$

\section{Results}

The six patients (five men and one woman) were between 21 and 70 years of age with a mean age of 54 years (Table 1). All patients had had manifest renal disease for only a short period (1-12 weeks). All patients presented with acute oliguric renal failure and rapid deterioration in renal function that required dialysis. In addition, two patients presented with dyspnoea and haemoptysis. All patients exhibited a nephritic urinary sediment, with slight proteinuria, and five were hypertensive (diastolic pressure $>90 \mathrm{~mm} \mathrm{Hg}$ ). None of these patients had the nephrotic syndrome. Serum C3 or C4, or both, was measured in three patients, and two had normal complement concentrations. A low serum C3 con-

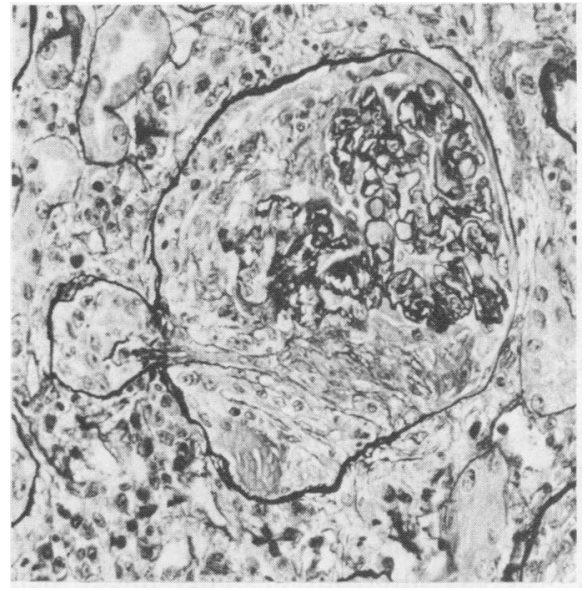

Fig. 1 Light microscopic appearance of a typical glomerulus showing cellular crescent compressing the capillary tuft. The interstitium exhibits a dense inflammatory infiltrate. Periodic acia methanamine silver stain. $\times 280$.

centration, along with a high antistreptolysin $\mathrm{O}$ titre, was found in one patient (case 2).

Three patients died as a result of extrarenal complications (cases 1,3 , and 5), one of them after renal transplantation (case 3). No patient had vasculitis. Other features are summarised in Table 1.

\section{LIGHT MICROSCOPY}

All six biopsy specimens showed classic histopathological features of crescentic glomerulonephritis (Fig. 1 and Table 2).

\section{IMMUNOPATHOLOGY}

The immunofluorescence findings are summarised in Table 3. Biopsy specimens from all six patients

Table 1 Summary of clinical and laboratory findings

\begin{tabular}{|c|c|c|c|c|c|c|c|c|}
\hline Case no & Age/Sex & $\begin{array}{l}\text { Disease } \\
\text { duration } \\
(w k)\end{array}$ & $\begin{array}{l}\text { Blood } \\
\text { pressure } \\
(\mathrm{mm} \mathrm{Hg})\end{array}$ & $\begin{array}{l}\text { Creatininel } \\
\text { blood urea } \\
\text { nitrogen } \\
(\mathrm{mg} / 100 \mathrm{ml})\end{array}$ & $\begin{array}{l}C 3 / C 4 \\
(m g / 100 \mathrm{ml})\end{array}$ & $\begin{array}{l}\text { Anti-GBM } \\
\text { serum/ } \\
\text { eluate }\end{array}$ & $\begin{array}{l}\text { Antistrepto- } \\
\text { lysin } O \text { titre }\end{array}$ & Additional information \\
\hline 1 & $63 / \mathrm{M}$ & $1-2$ & $155 / 90$ & $18 / 132$ & ND & $+1+$ & $<100 \mathrm{U}$ Todd & $\begin{array}{l}\text { Acute myocardial infarction } 6 \\
\text { weeks earlier. Rupture of } \\
\text { aortic aneurysm. Died. }\end{array}$ \\
\hline 2 & $21 / M$ & 1 & $160 / 95$ & $7 / 67$ & $30 / N D$ & $+/+$ & $1200 \mathrm{U}$ Todd & $\begin{array}{l}\text { Rheumatic fever } 10 \text { years and } 3 \\
\text { years earlier. Sore throat } 1 \\
\text { month before admission. } \\
\text { Nephrectomy. }\end{array}$ \\
\hline 3 & $40 / \mathrm{M}$ & 4 & $180 / 90$ & $10 / 117$ & $116 / N D$ & $+1+$ & 333 U Todd & $\begin{array}{l}\text { Nephrectomy. Renal transplan- } \\
\text { tation. Died from perforated } \\
\text { peptic ulcer } 3 \text { months later. }\end{array}$ \\
\hline 4 & 70/M & 12 & $155 / 90$ & $14 / 115$ & $98 / 38$ & $+/ N D$ & ND & Dyspnoea. Haemoptysis. \\
\hline 5 & $64 / M$ & $1-2$ & $150 / 90$ & $15 / 250$ & ND/ND & $+1+$ & $<100$ U Todd & $\begin{array}{l}\text { Haemoptysis. Perforation of } \\
\text { sigmoid colon. Peritonitis. } \\
\text { Septic shock. Died. }\end{array}$ \\
\hline 6 & $63 / F$ & 1 & $180 / 80$ & $16 / 30$ & ND/ND & $+/ \mathrm{ND}$ & ND & Perforated bowel. \\
\hline
\end{tabular}

$\mathrm{ND}=$ Not done 
Table 2 Light microscopic findings

\begin{tabular}{|c|c|c|}
\hline Features & No positive & $\begin{array}{l}\text { \% Average } \\
\text { (range) }\end{array}$ \\
\hline $\begin{array}{l}\text { Glomerular epithelial and } \\
\text { fibroepithelial crescents }\end{array}$ & $6 / 6$ & \multirow{4}{*}{$\begin{array}{l}68 \% \\
(16 \%-100 \%) \\
25 \% \\
(4 \%-76 \%)\end{array}$} \\
\hline Glomerular obsolescence & $6 / 6$ & \\
\hline $\begin{array}{l}\text { Neutrophils in glomeruli } \\
\text { Multinucleated cells in glomeruli } \\
\text { Fibrin (glomeruli and crescents) }\end{array}$ & $\begin{array}{l}6 / 6 \\
1 / 6 \\
6 / 6\end{array}$ & \\
\hline $\begin{array}{l}\text { Tubular atrophy, interstitial fibrosis, } \\
\text { and chronic inflammation } \\
\text { Thickening of vascular walls }\end{array}$ & $6 / 6$ & \\
\hline
\end{tabular}

showed sharp, continuous, linear deposits of IgG $(3+)$ (Fig. 2), and all but one had IgM deposits (1+) along the GBM. The accompanying $\mathrm{C} 3$ deposits were similarly linear $(1-3+)$ in three biopsy specimens, whereas interrupted, short linear deposits $(1-2+)$ were seen in one biopsy specimen, and short linear and granular deposits $(2+)$ were noted in another; exclusively granular deposits of $\mathrm{C} 3(1+)$ were seen in a single biopsy specimen (Fig. 3). All the $\mathrm{C} 3$ deposits were found mostly along the capillary basement membranes. Linear and short linear deposits of $\mathrm{Clq}(1-2+)$ were seen in two biopsy specimens. Linear deposits of $\mathrm{C} 4$ were observed in one and both short linear and granular deposits were found in another $(1-2+)$. Fibrin related antigens $(2-3+)$ were observed within the crescents in all the specimens. No $\operatorname{IgA}$, albumin, or alpha-2macroglobulin deposits were found in the glomeruli.

Information on anti-GBM activity in sera and renal eluates is given in Table 1 . Circulating antiGBM antibody was detectable in the sera of five patients by indirect immunofluorescence assay and in the sera of all three patients tested by radioimmunoassay. Anti-GBM activity was found in all of the four eluates that were tested. Radioimmunoassay for circulating immune complexes performed on sera from two patients (cases 5 and 6 ) yielded negative results.

\section{ELECTRON MICROSCOPY}

The ultrastructural findings are summarised in Table 4. Scattered, definitive, electron dense deposits conforming to immunoreactants were seen in a random
Rajaraman, Pinto, Cavallo

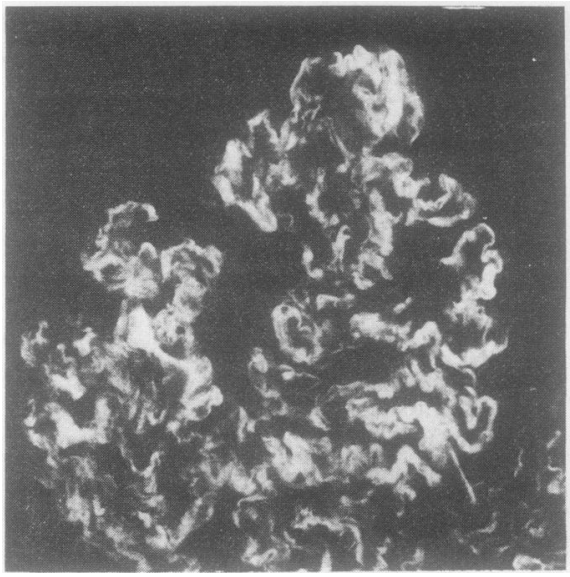

Fig. 2 Immunofuorescent photomicrograph showing a glomerulus exhibiting linear IgG staining along the glomerular capillary basement membranes. $\times 320$.

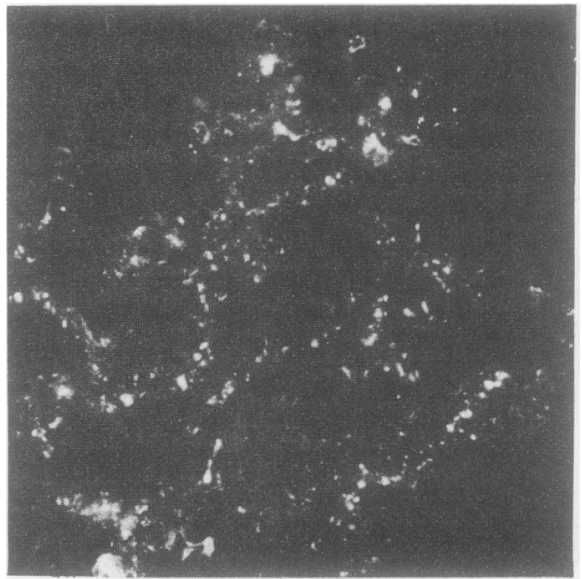

Fig. 3 Immunofuorescent photomicrograph showing predominantly granular deposits of $C 3$ along the glomerular capillary basement membranes. $\times 320$.

Table 3 Direct immunoftuorescence microscopy findings in glomeruli

\begin{tabular}{llllll}
\hline Case no & IgG & $I g M$ & $C 3$ & $C 1 q$ & $C 4$, \\
\hline 1 & $3+(\mathrm{L})$ & $1+(\mathrm{L})$ & $3+(\mathrm{L})$ & Negative & \\
2 & $3+(\mathrm{L})$ & $1+(\mathrm{L})$ & $3+(\mathrm{L})$ & Negative & \\
3 & $3+(\mathrm{L})$ & $1+(\mathrm{L})$ & $1+(\mathrm{L})$ & $1+(\mathrm{L})$ & $2+(\mathrm{SL}$ and G) \\
4 & $3+(\mathrm{L})$ & Negative & $2+(\mathrm{SL}$ and G) & $1+-2+(\mathrm{SL})$ & $1+(\mathrm{L})$ \\
5 & $3+(\mathrm{L})$ & $1+(\mathrm{L})$ & $1+-2+(\mathrm{SL})$ & Negative & Negative \\
6 & $3+(\mathrm{L})$ & $1+(\mathrm{SL})$ & $1+(\mathrm{G})$ & \\
\hline
\end{tabular}

IgA, albumin and alpha-2-macroglobulin were not present in any of the specimens. Fibrin $(2-3+)$ was observed within the crescents in all the biopsies. $\mathrm{L}=$ linear, $\mathrm{SL}=$ short linear, $\mathrm{G}=$ granular. 


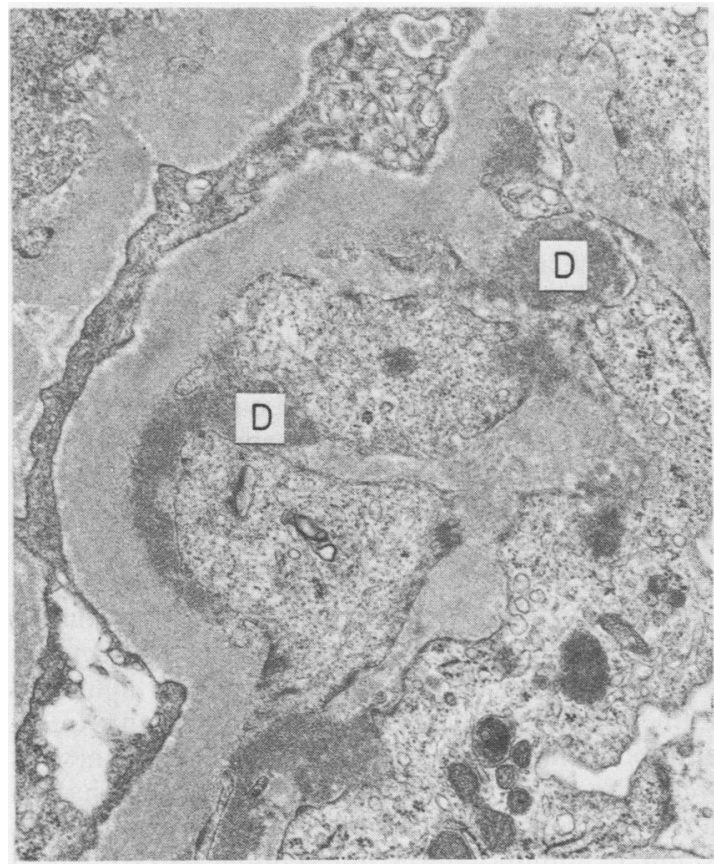

Fig. 4 Electron photomicrograph illustrating subendothelial electron dense deposits $(D)$ along duplicated basement membrane. $\times 15400$.

distribution (Fig. 4 and 5). Subepithelial deposits were found in three of the six specimens, subendothelial deposits in three of them, intramembranous deposits in five, and mesangial deposits in three. The patterns of deposition did not correspond to any typical category of immune complex mediated nephritis. The uninvolved basement membranes showed non-specific features commonly seen in uncomplicated anti-GBM disease.

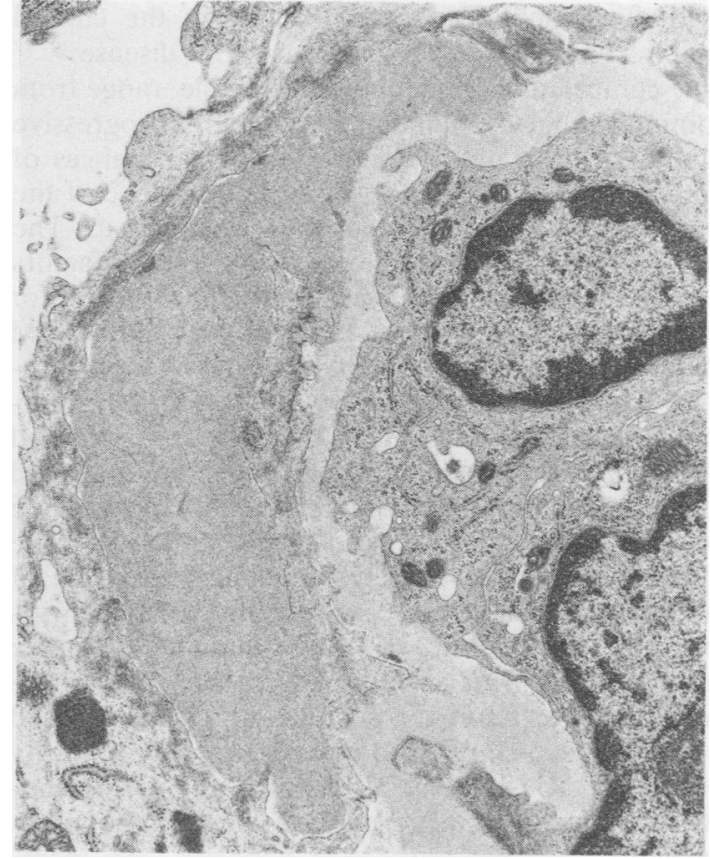

Fig. 5 Electron photomicrograph illustrating a large subepithelial deposit. $\times 10850$.

\section{Discussion}

Anti-GBM disease comprises about $2-5 \%$ of immunologically mediated human glomerulonephritides. Diagnosis rests on detection of antibodies bound to the GBM in a continuous, linear configuration and demonstration of anti-GBM activity in sera or renal eluates, or both.

In the past decade several reports have emphas-

Table 4 Findings on electron microscopy

\begin{tabular}{lll}
\hline Case no & Electron dense deposits & Other ultrastructural features (common to all biopsies) \\
\hline 1 & $\begin{array}{l}\text { Subepithelial } \\
\text { Subendothelial } \\
\text { Intramembranous } \\
\text { Mesangial }\end{array}$ & $\begin{array}{l}\text { Glomerular basement membrane } \\
\text { Thickening } \\
\text { Attenuation } \\
\text { Wrinkling } \\
\text { Disruption } \\
\text { Rarefaction } \\
\text { Loss of demarcation of lamina rara and densa }\end{array}$ \\
2 & $\begin{array}{l}\text { Intramembranous } \\
\text { Subendothelial }\end{array}$ & $\begin{array}{l}\text { Formation of basement membrane like material } \\
\text { Intramembranous }\end{array}$ \\
$\begin{array}{l}\text { Intramembranous } \\
\text { Subendothelial }\end{array}$ & $\begin{array}{l}\text { Intramembranous loop collapse } \\
\text { Mesangial }\end{array}$ & Cellular crescents \\
5 & $\begin{array}{l}\text { Subepithelial } \\
\text { Subepithelial }\end{array}$ & Fibrin in the crescents \\
6 & Mesangial &
\end{tabular}


ised the pronounced heterogeneity in the clinical manifestations and course of anti-GBM disease..$^{20-22}$ The clinical manifestations, for example, range from minimal renal dysfunction to a rapidly progressive clinical course and also include a few instances of spontaneous remission or, rarely, persistence of the pathogenetic mechanism for more than a year. The heterogeneity of the inducing or associated factors has also been emphasised. Moorthy et al,,$^{14}$ for example, reported three patients with anti-GBM nephritis superimposed on a pre-existing membranous nephropathy; they postulated that the intermingling of immune complexes with newly formed basement membrane material might have altered the antigenicity of the basement membrane, leading to the production of anti-GBM antibody. The reverse sequence-namely, the superimposition of an immune complex disease on anti-GBM nephritis or the induction of an immune complex glomerulonephritis with basement membrane antigens - has also been postulated..$^{13}$ This proposed sequence is in contrast to that reported by Moorthy et al $^{14}$ and Klassen et al, (in which anti-GBM nephritis occurred in a pre-existing membranous nephropathy) in that anti-GBM nephritis and membranous nephropathy are hypothesised to have been produced simultaneously by a mechanism analogous to one initiated by heterologous nephrotoxic antibodies $^{23}$ or by autologous anti-GBM antibodies (such as those that have been produced in experimental animals).$^{24}$ Serological evidence of circulating immune complexes superimposed on preexisting anti-GBM disease has been put forward by Pussell et $a l^{12}$ and Vanhille $e t a l$, ${ }^{15}$ where the circulating immune complexes appearing late in the course of the disease allegedly contributed to worsening of organ disease (lung and kidney) and the patient's clinical condition.

The six patients reported here had documented anti-GBM disease as shown by $(a)$ rapidly progressive (crescentic) glomerulonephritis, $(b)$ linear IgG deposits along the GBM by immunofluorescence, and $(c)$ anti-GBM antibodies in the sera or eluates, or both. In addition, immunofluorescence and ultrastructural studies indicated the presence of associated granular deposits of immunoreactants along the GBM or the mesangium, or both, in all six biopsy specimens, although supportive serological evidence of circulating immune complexes was not obtained in the two patients (cases 5 and 6 ) whose sera were tested by the C1q binding assay and the Raji cell assay. Immunofluorescence showed granular deposits in only two of these patients.

The temporal relation between the deposition of immunoreactants and anti-GBM antibody production in our patients could not be ascertained because serial serological assays for anti-GBM antibody and circulating immune complexes were not performed. Only one patient (case 2), however, had a clinical course that was complicated by an infectious episode. The streptococcal infection in this patient could represent a coincidence, but speculation as to the role of streptococcal antigens binding to and altering the antigenicity of the GBM seems theoretically possible. None of the other five patients had a clinical history or laboratory findings that suggested an antecedent viral or bacterial infection, and none had a pre-existing glomerular disease. Thus it is not likely that immune complexes associated with infection provided the necessary conditions for a grafted immune complex disease in those five patients. On the other hand it is possible that fixation of antiGBM antibody in the GBM might augment or facilitate the glomerular deposition of circulating immune complexes. Such a synergistic effect has been shown in animal models by Trevillian and Cameron. ${ }^{25}$ It is also conceivable that anti-GBM antibodies might bind to intact GBM antigen(s) as well as to freed, entrapped, GBM antigens, the latter to form an immune aggregate and result in the granular immunofluorescent staining pattern which we observed in our biopsy specimens. Such a hypothesis is supported by the findings of Jennette $e t$ $a l,{ }^{16}$ who reported findings of concurrent anti-GBM disease and immune complex in a biopsy specimen in which the linear and granular deposits showed an IgG subclass restriction (IgG1 and IgG4) similar to that found in 13 other cases of uncomplicated anti-GBM antibody disease. It is also possible that the immune aggregates are composed of rheumatoid factors or anti-idiotypic antibodies and that the binding takes place in situ (in the damaged glomerular capillary wall or mesangia). Presumptive evidence for such a mechanism has been found by Sugisaki $e a^{26}$ in their investigation of various forms of glomerulonephritis mediated by immune complexes. The two latter possibilities would also explain the failure to detect circulating immune complexes in the sera of these patients.

Our study focused on an interesting and rare finding that may bear important pathogenetic connotations that are, as yet, undefined. We suspect that with increasing awareness similar pathological entities will be identified more often, and we propose that prospective investigative studies should include serial assays of anti-GBM antibody and circulating immune complexes in the serum to define the temporal relation of this association. If we assume that circulating immune complexes can be detected and isolated, then the use of techniques such as polyacrylamide gel electrophoresis and transfer of immunoreactants to nitrocellulose mem- 
branes might afford an opportunity to gain some insight into the antigen(s) and antibodies that are concerned. Until then, and also until the specificity of the antibody to the putative antigen(s) has been determined, the association of anti-GBM disease and immune complex nephritis will remain a clinical curiosity to challenge the immunopathologist.

The authors thank Dr Curtis B Wilson for performing the radioimmunoassays for immune complexes and antibasement membrane antibody activity. Mrs Earline Goss provided expert secretarial help and Ms Renee Robillard gave editorial suggestions in the preparation of this manuscript.

\section{References}

' Dixon FJ. The pathogenesis of glomerulonephritis. Am J Med 1968;44:493-8.

2 Wilson CB, Dixon FJ. Diagnosis of immunopathologic renal disease. Kidney Int 1974;5:389-401.

${ }^{3}$ Beirne GJ, Wagnild JP, Zimmerman SW, Macken PD, Burkholder PM. Idiopathic crescentic glomerulonephritis. Medicine 1977;56:349-81.

${ }^{4}$ Klassen J, Elwood C, Grossberg AL, et al. Evolution of membranous nephropathy into anti-glomerular-basementmembrane glomerulonephritis. $N$ Engl J Med 1974;290: 1340-4.

s Sternlieb I, Bennett B, Scheinberg IH. D-Penicillamine induced Goodpasture's syndrome in Wilson's disease. Ann Intern Med 1975;82:673-6.

- Wilson CB, Smith RC. Goodpasture's syndrome associated with influenza A2 virus infection. Ann Intern Med 1972;76:91-4.

' Curtis JJ, Bhathena D, Leach RP, Galla JH, Lucas BA, Luke RG. Goodpasture's syndrome in a patient with the NailPatella syndrome. Am J Med 1976;61:401-6.

* Beirne GJ, Brennan JT. Glomerulonephritis associated with hydrocarbon solvents. Arch Environ Health 1972;25:365-9.

' Hume DM, Sterling WA, Weymouth RJ, Siebel HR, Madge GE, Lee HM. Glomerulonephritis in human renal homotransplants. Transplant Proc 1970;2:361-412.

1" Wilson CB. Nephritogenic antibody mechanisms involving antigens within the glomerulus. Immunol Rev 1981;55:257-97.

"Tung KS Woodroffe AJ, Ahlin TD, Williams RC Jr, Wilson CB. Application of the solid phase $\mathrm{C} 1 \mathrm{q}$ and Raji cell radioimmune assays for the detection of circulating immune complexes in glomerulonephritis. J Clin Invest 1978;62:61-72.

12 Pussell BA, Lockwood CM, Rees AJ, Pinching AJ, Peters DK. Circulating immune complexes in antiglomerular basement membrane disease. Kidney Int 1979;16:661A.

${ }^{13}$ Pasternack A, Tornroth T, Linder E. Evidence of both anti-
GBM and immune complex mediated pathogenesis in the initial phase of Goodpasture's syndrome. Clin Nephrol 1978;9:77-85.

${ }^{14}$ Moorthy AV, Zimmerman SW, Burkholder PM, Harrington AR. Association of crescentic glomerulonephritis with membranous glomerulonephropathy: A report of three cases. Clin Nephrol 1976;6:319-25.

15 Vanhille P, Raviart B, Morel-Maroger L, Mahieu P, Santoro F. Circulating immune complexes appearing in Goodpasture's syndrome. Br Med J 1980;280:1166-7.

16 Jennette JC, Lamanna RW, Burnette JP, Wilkman AS, Iskander SS. Concurrent antiglomerular basement membrane antibody and immune complex mediated glomerulonephritis. Am J Clin Pathol 1982;78:381-6.

17 Richman AV, Rifkin SI, McAllister CJ. Rapidly progressive glomerulonephritis. Combined antiglomerular basement membrane antibody and immune complex pathogenesis. Hum Pathol 1981;12:597-604.

${ }^{18}$ Davis BK, Cavallo T. Membranoproliferative glomerulonephritis. Localization of early components of complement in glomerular deposits. Am J Pathol 1976;84: 283-98.

${ }^{19}$ Lewis EJ, Cavallo T, Harrington JT, Cotran RS. An immunopathologic study of rapidly progressive glomerulonephritis in the adult. Hum Pathol 1971;2:185-208.

${ }^{20}$ McPhaul JJ Jr, Mullins JD. Glomerulonephritis mediated by antibody to glomerular basement membrane: Immunological, clinical, and histopathological characteristics. J Clin Invest 1976;57:351-61.

${ }^{21}$ Teague CA, Doak PB, Simpson IJ, Rainer SP, Herdson PB. Goodpasture's syndrome: An analysis of 29 cases. Kidney Int 1978; 13:492-504.

${ }^{22}$ Zimmerman SW, Varanasi UR, Hoff B. Goodpasture's syndrome with normal renal function. Am J Med 1979;66:16371.

${ }^{23}$ Unanue ER, Dixon FJ. Experimental glomerulonephritis: Immunological events and pathogenetic mechanisms. $A d v$ Immunol 1967;6: 1-90.

${ }^{24}$ Lerner RA, Dixon FJ. Transfer of ovine experimental allergic glomerulonephritis (EAG) with serum. J Exp Med 1966;124:431-42.

${ }^{25}$ Trevillian P, Cameron JS. The interaction of anti-glomerular basement membrane antibody deposition with immune elimination of bovine serum albumin in the rabbit. Clin Exp Immunol 1979;35:338-49.

${ }^{26}$ Sugisaki T, Sciwachi S, Yonekura M, et al. High-dose intravenous gammaglobulin for membranous nephropathy, membranoproliferative glomerulonephritis and lupus nephritis. Fed Proc 1982;41:692.

Requests for reprints to: Dr S Rajaraman, The University of Texas Medical Branch at Galveston, Department of Pathology, 201 Keiller Building, Galveston, Texas 77550, USA 